\section{UTF 25 - Early bread wheat cultivar with white flour}

\author{
Giovani Benin ${ }^{1 *}$, Anderson Simionato Milioli ${ }^{1}$, Daniela Meira ${ }^{1}$, \\ Leomar Guilherme Woyann ${ }^{1}$, Antonio Henrique Bozi ${ }^{1}$, Ana \\ Claudia Rosa ${ }^{1}$, Laura Alexandra Madella ${ }^{1}$, Maiara Cecília \\ Panho' ${ }^{1}$, Lucas Vinicius Dallacorte ${ }^{1}$, Rogê Afonso Tolentino \\ Fernandes ${ }^{1}$, Vinícius Kunz Fernandes ${ }^{1}$, Fabiana Barrionuevo ${ }^{1}$, \\ Alana Madureira ${ }^{1}$, Eduardo Beche ${ }^{1}$, Cristiano Lemes da Silva ${ }^{1}$, \\ Elesandro Bornhofen ${ }^{1}$, Lucas Berger Munaro ${ }^{1}$, Matheus \\ Henrique Todeschini ${ }^{1}$ and Thiago Duarte ${ }^{1}$
}

\begin{abstract}
The wheat cultivar UTF 25 is recommended for wheat-growing regions 1 and 2 of Paraná and Santa Catarina states. It has a good disease resistance, early cycle, and high grain yield potential, with an average yield of $3.511 \mathrm{~kg}$ $\mathrm{ha}^{-1}$. It is classified as bread wheat with white flour.
\end{abstract}

Keywords: Triticum aestivum L., grain yield, disease resistance, baking quality.

\section{INTRODUCTION}

Wheat is the second most produced cereal in the world, with a production of 763 million t year-1 (FAO 2020). In Brazil, the southern region is responsible for more than $85 \%$ of national wheat production, even though the domestic demand is higher than the production (CONAB 2019). Thus, wheat breeding programs are very important in the development of more adaptable and highyielding cultivars.

The development of high-yield genetics and improvements in management practices allowed increased grain yield from $700 \mathrm{~kg} \mathrm{ha}^{-1}$ in the 1940 s to more than $2.700 \mathrm{~kg} \mathrm{ha}^{-1}$ currently (CONAB 2019). Beche et al. (2014) evaluated wheat cultivars released in Brazil between 1940 and 2009 and observed a genetic gain of $29 \mathrm{~kg} \mathrm{ha}^{-1}$ year $^{-1}\left(0.92 \%\right.$ year $\left.^{-1}\right)$. Similar results were presented by Bornhofen et al. (2018) and Woyann et al. (2019), indicating a significant genetic gain for this crop in Brazil. However, to meet food demand by 2050, the annual increase in food production needs to be on the order of $2.4 \%$ (Ray et al. 2013). To this end, the release of new, more productive cultivars is essential for increasing genetic gains.

The Federal University of Technology-Paraná (UTFPR) wheat breeding program began in 2006. The main objectives of the UTFPR wheat breeding program are the development of cultivars adapted to the southwestern region of Paraná and the western region of Santa Catarina and the training and mentoring of future plant breeders and scientists. Undergraduate and graduate students
Crop Breeding and Applied Biotechnology 20(4): e344920414, 2020 Brazilian Society of Plant Breeding. Printed in Brazil http://dx.doi.org/10.1590/198470332020v20n4c67

. 
collaborate in conducting yield trials, emasculations, crosses, field experiments, and lab activities and evaluating segregating populations. Several studies were based on data obtained by this program, including dozens of monographs, 20 master's degree theses, and five doctoral dissertations.

The cultivar name, UTF 25, was chosen in honor of the $25^{\text {th }}$ anniversary of the Agronomy course at UTFPR-Pato Branco. The origin of UTFPR relied on the Centro Federal de Educação Tecnológica do Paraná (CEFET-PR). In 2005, it was transformed into the first Brazilian Federal University of Technology. UTF 25 is adapted to wheat-growing regions 1 and 2 of Paraná and Santa Catarina states. It is an early high-yielding bread wheat cultivar with good disease resistance, white flour, and good baking quality; the aim is to supply farmer and industry needs. UTF 25 is an excellent option for wheat farmers in the southwestern region of Paraná and the western region of Santa Catarina owing to its good adaptation to these environments. More evaluations in other Value of Cultivation and Use (VCU) regions are being carried out to determine the expansion in the recommendation.

\section{BREEDING METHODS}

The new wheat cultivar UTF 25 was derived as an $\mathrm{F}_{4: 5}$ head row from a cross between wheat cultivars Ônix $x$ Marfim. The cultivar Ônix, released in 2002, is classified as a bread wheat, and it has strong pre-harvest sprouting resistance. The bread wheat cultivar Marfim, released in 2007, has excellent baking quality, with high stability, and this cultivar has moderate resistance to rust. The cross was performed in 2009, and the $F_{1}$ plants were grown in the UTFPR greenhouse in 2010 and bulk-harvested. The segregant populations $F_{2}$ to $F_{6}$ were produced under field conditions at the UTFPR Research farm in Pato Branco (lat $26^{\circ} 10^{\prime} 34^{\prime \prime} \mathrm{S}$, long $52^{\circ} 41^{\prime} 23^{\prime \prime} \mathrm{W}$, alt $760 \mathrm{~m}$ asl). In 2011, the $\mathrm{F}_{2}$ plants were selected for plant architecture and disease resistance, and later selected spikes were bulk-threshed following a modified mass method. A seed sample was used to establish the next generation. In the $F_{3}$ population, a bulk of plants with a higher number of spikes and proper spike length was selected. In 2013, individual $F_{4}$ plants were selected for the number and length of spikes, plant architecture, and disease resistance. Each plant was threshed individually, and an $\mathrm{F}_{4: 5}$ head row was originated. UTF 25 originated from one of the $F_{4: 5}$ head rows evaluated in 2014. Subsequently, it was tested in UTFPR wheat yield trials from 2015 to 2016 and in VCU trials from 2017 to 2018. The cultivar UTF 25 was derived from the best yielding line (UTFT 141457) across years and locations.

\section{TRAITS AND PERFORMANCE}

UTF 25, previously tested as UTFT 141457, has been evaluated in UTFPR wheat yield trials since 2015 to 2016 at the UTFPR Research Farm in Pato Branco and in VCU tests in 2017 and 2018. It showed superior performance in yield trials compared with commercial checks (Table 1).

Table 1. Mean grain yield ( $\mathrm{kg} \mathrm{ha}^{-1}$ ) of cultivar UTF 25 and check cultivars in wheat-growing regions 1 and 2 of Santa Catarina (SC) and Paraná (PR) states in the 2017 and 2018 crop seasons

\begin{tabular}{|c|c|c|c|c|c|c|}
\hline \multirow{2}{*}{ Region/State } & & \multicolumn{2}{|c|}{2017} & \multicolumn{2}{|c|}{2018} & \multirow{2}{*}{$\begin{array}{l}\text { Grand } \\
\text { mean }\end{array}$} \\
\hline & & SC & PR & SC & PR & \\
\hline \multirow{4}{*}{ VCU 1} & UTF 25 & 3089 a** & $2634 a$ & 4829 a & $5545 a$ & 4024 \\
\hline & $\mathrm{T} 1 *$ & $2747 b$ & $2434 b$ & $4333 \mathrm{~b}$ & $4947 \mathrm{~b}$ & 3615 \\
\hline & $\mathrm{T} 2$ & $2900 \mathrm{a}$ & $2683 a$ & $4672 \mathrm{a}$ & $5194 \mathrm{~b}$ & 3862 \\
\hline & Tmean & 2823 & 2558 & 4503 & 5070 & 3739 \\
\hline \multirow{2}{*}{ VCU 2} & UTF 25 & $1966 \mathrm{a}$ & $2318 a$ & $4081 \mathrm{a}$ & $3625 a$ & 2998 \\
\hline & Tmean & 1965 & 2364 & 3665 & 3368 & 2841 \\
\hline \multirow{4}{*}{ Grand mean } & UTF 25 & 2528 & 2476 & 4455 & 4585 & 3511 \\
\hline & $\mathrm{T} 1$ & 2372 & 2400 & 3887 & 4318 & 3244 \\
\hline & $\mathrm{T} 2$ & 2417 & 2522 & 4281 & 4122 & 3335 \\
\hline & Tmean & 2394 & 2461 & 4084 & 4219 & 3290 \\
\hline
\end{tabular}

* T1: TBIO Iguaçu (2017) and TBIO Tibagi (2018); T2: TBIO Tibagi (2017) and TBIO Toruk (2018); Tmean: mean grain yield of check cultivars. * Means followed by the same letter did not differ statistically according to Tukey's test $(p<0.05)$. ' Min: minimum value observed in seven samples; Max: maximum value observed in seven samples. 
Table 2. Means of gluten strength $\left(\mathrm{W}, 10^{-4} \mathrm{~J}\right)$, falling number ( $\left.F N, \mathrm{~min}\right)$, tenacity/extensibility ratio $(\mathrm{P} / \mathrm{L})$, yield stability $(\mathrm{E}, \mathrm{min})$, and flour color (L, lightness; color a, color b, chromaticity) of cultivar UTF 25 and check cultivars in wheat-growing regions 1 and 2 of Paraná and Santa Catarina states in 2017 and 2018

\begin{tabular}{|c|c|c|c|c|c|c|c|c|c|c|c|}
\hline \multirow{2}{*}{ Cultivar } & \multicolumn{3}{|c|}{$\mathbf{W}\left(10^{-4} \mathrm{~J}\right)$} & \multicolumn{3}{|c|}{$\mathbf{F N}(\min )$} & \multirow{2}{*}{$\begin{array}{c}\mathrm{P} / \mathrm{L} \\
\text { (ratio) }\end{array}$} & \multirow{2}{*}{$\begin{array}{c}\mathbf{E} \\
(\mathrm{min})\end{array}$} & \multirow[t]{2}{*}{$\mathbf{L}$} & \multirow[t]{2}{*}{$a$} & \multirow[t]{2}{*}{ b } \\
\hline & $\operatorname{Min}^{1}$ & Max & Mean & Min & Max & Mean & & & & & \\
\hline UTF 25 & 233 & 291 & $245 a$ & 224 & 297 & $245 a$ & $0.39 a$ & $13.3 \mathrm{a}$ & $94.55 \mathrm{a}$ & $-0.50 a$ & $9.75 \mathrm{~b}$ \\
\hline $\mathrm{T} 1$ & 231 & 295 & $222 a$ & 228 & 294 & $257 a$ & $0.38 \mathrm{a}$ & $8.1 \mathrm{~b}$ & $94.72 \mathrm{a}$ & $-0.33 b$ & $8.23 c$ \\
\hline $\mathrm{T} 2$ & 242 & 318 & $272 a$ & 241 & 297 & $275 a$ & $0.46 \mathrm{a}$ & $7.3 \mathrm{~b}$ & $92.75 \mathrm{~b}$ & $-0.30 b$ & $12.0 \mathrm{a}$ \\
\hline Tmean & & & 247 & & & 266 & 0.42 & 7.7 & 93.73 & -0.315 & 10.115 \\
\hline
\end{tabular}

* T1: TBIO Iguaçu (2017) and TBIO Tibagi (2018); T2: TBIO Tibagi (2017) and TBIO Toruk (2018); Tmean: mean grain yield of check cultivars. *Means followed by the same letter did not differ statistically according to Tukey's test $(p<0.05)$. 'Min: minimum value observed in seven samples; Max: maximum value observed in seven samples.

VCU tests were conducted in several environments of the wheat-growing regions 1 and 2 of Paraná and Santa Catarina, ranging from $1.839 \mathrm{~m}$ to $1.035 \mathrm{~m}$ asl in Region 1 and between $688 \mathrm{~m}$ and $910 \mathrm{~m}$ asl in Region 2. In Region 1, the tests were conducted in Palmas-PR, Clevelândia-PR, Canoinhas-SC, and Campos Novos-SC. Region 2 tests were conducted in Pato Branco-PR, Renascença-PR, Abelardo Luz-SC, and Campo Erê-SC. The test locations were the same for the two years of evaluation. The experiments were arranged in a randomized complete block design with three replications. The plots consisted of six rows with a row spacing of $0.17 \mathrm{~m}$ and row length of $5 \mathrm{~m}$. Fertilization was applied according to the soil analysis of each environment, and pest and disease control was conducted according to recommended management practices (Comissão 2017).

In the VCU tests, the evaluated traits were days from emergence to heading, days from emergence to maturity, plant height, lodging, soil aluminum sensibility, shattering resistance, and disease resistance. The total plot area was harvested, and the grain yield, 1000-grain weight, hectoliter weight, and pre-harvest sprouting were evaluated. The baking quality traits evaluated were gluten strength $\left(W, 10^{-4} \mathrm{~J}\right)$, falling number $(F N, s)$, relative tenacity/extensibility ratio $(P / L)$, yield stability ( $E, \mathrm{~min}$ ), and flour color determined by the L ? a ? b a system (lightness and chromaticity coordinates), according to the international standard for color measurements.

Cultivar UTF 25 showed superior grain yield performance to check cultivars in the two test years (2017 and 2018), with $7.6 \%$ and $5.5 \%$ higher grain yields than the average of checks in wheat-growing regions 1 and 2, respectively (Table 1). UTF 25 showed an average grain yield of $3.511 \mathrm{~kg} \mathrm{ha}^{-1}$, and that of the check cultivars was $3.290 \mathrm{~kg} \mathrm{ha}^{-1}$, representing a $6.7 \%$ better yield. Due to the good agronomic performance of cultivar UTF 25 , it was indicated for cultivation in wheatgrowing regions 1 and 2 of Paraná and Santa Catarina states. Cultivar UTF 25 is registered by the Registro Nacional de Cultivares (nr. 44017) and protected (nr. 20200104).

For baking quality traits, cultivar UTF 25 was classified as a bread wheat (Table 2). It showed an average gluten strength of $245 \mathrm{~W}$, falling number of $245 \mathrm{~s}$, relative tenacity/extensibility ratio of 0.39 , stability of $13.3 \mathrm{~min}$, white flour color (lightness of 94.55 [COL L] and chromaticity of -0.5 [COL a] and 9.75 [COL b]).

\section{OTHER TRAITS OF IMPORTANCE}

Cultivar UTF 25 has a semi-erect vegetative habit and pending or intermediate flag leaf position, with semi-long, semi-dense, and fusiform or oblong spikes. UTF 25 plant height is medium or high, with an average of $95 \mathrm{~cm}$. The average cycle was classified as early, with 73 days from emergence to heading and 123 days from emergence to maturity, varying according to the sowing date and weather conditions. The mean hectoliter weight was $79.1 \mathrm{~kg} \mathrm{hL}^{-1}$, and the 1000 -grain weight was $34.5 \mathrm{~g}$. Despite the tall plant height, the lodging resistance of the cultivar is good, and it was classified as moderately resistant. Furthermore, UTF 25 showed moderate resistance to pre-harvest sprouting, shattering resistance, and tolerance to soil aluminum.

In the VCU trials in 2017 and 2018, the responses of cultivar UTF 25 to main wheat diseases were evaluated. UTF 25 was classified as moderately susceptible to glume blotch (Stagonospora nodorum), head blight (Fusarium graminearum), and barley yellow dwarf virus and moderately resistant to powdery mildew (Blumeria graminis tritici), leaf rust (Puccinia recondita tritici), and leaf spot (Bipolares sorokiniana and Drechslera tritici repentis). Thus, cultivar UTF 25 showed good disease resistance. 


\section{SEED PRODUCTION}

The UTFPR contracts seed companies for multiplication and trade of the cultivar, according to Brazilian law nr. 9456/97. Cultivar UTF 25 was released into the market in 2020, with an availability of nearly 500 40-kg bags of seeds for the 2021 winter season. For the 2022 winter season, a much higher seed volume will be available for farmers.

\section{REFERENCES}

Beche E, Benin G, Silva CL, Munaro LB and Marchese A (2014) Genetic gain in yield and changes associated with physiological traits in Brazilian wheat during the 20th century. European Journal of Agronomy 61: 49-59.

Bornhofen E, Todeschini MH, Stoco MG, Madureira A, Marchioro VS, Storck L and Benin G (2018) Wheat yield improvements in Brazil: Roles of genetics and environment. Crop Science 58: 1-12.

Comissão - Comissão Brasileira de Pesquisa de Trigo e Triticale (2017) Informações técnicas para trigo e triticale - safra 2017. Empresa Brasileira de Pesquisa Agropecuária, Londrina, 242p. Available at <https://ainfo.cnptia.embrapa.br/digital/bitstream/item/155787/1/ Informacoes-Tecnicas-para-Trigo-e-Triticale-Safra-2017-OL.pdf>. Accessed on March 7, 2020.
CONAB - Companhia Nacional de Abastecimento (2019) Acompanhamento da safra brasileira de grãos. Available at <https://www.conab.gov.br/ info-agro/safras/graos/boletim-da-safra-de-graos>. Accessed on March 18, 2020.

FAO - Food and Agriculture Organization of the United Nations (2020) World food situation. Available at <http://www.fao.org/ worldfoodsituation/csdb/en/>. Accessed on March 1, 2020.

Ray DK, Mueller ND, West PC and Foley JA (2013) Yield trends are insufficient to double global crop production by 2050 . PloS One 8: e66428.

Woyann LG, Zdziarski AD, Zanella R, Rosa AC, Castro RL, Caeirão E, Toigo MDC, Storck L, Wu J and Benin G (2019) Genetic gain over 30 years of spring wheat breeding in Brazil. Crop Science 59: 2036-2045. 